\title{
The Wish to Stop Time: Margaret Atwood's Oryx and Crake
}

Tatiana de Freitas Massuno

Pontifical Catholic University of Rio de Janeiro

Correspondence | tatiana.massuno@gmail.com

Citation | Massuno, Tatiana de Freitas. 2019. “The Wish to Stop Time: Margaret Atwood's Oryx and Crake.” Journal of Big

History, IV (1): 13-20. http://dx.doi.org/10.22339/jbh.v4i1.4170.

DOI | http://dx.doi.org/10.22339/jbh.v4i1.4170

\begin{abstract}
What if humans continue to pursue "more and better"? What if we continue living within our safe anthropocentric boundaries? What if we ignore the question of when too much is too much? Margaret Atwood's "speculative fiction" presents no new worlds, as Atwood's world resembles our own; her novels present, on the other hand, what-if realities. By extrapolating trends, Oryx and Crake poses the afore-mentioned questions within Modernity's framework. Atwood's novel revisits key concepts such as time and subjectivity and brings progression to a halt. What may the wish to stop time, our human condition, result in, after all? Modernity and its concepts are under scrutiny in a novel in which climate change and nature seem to have been surpassed. The present paper aims, therefore, at investigating what this "us without a world" story, which becomes a "world without us" one, can tell us about the pursuits of Modernity and their repercussions: that is, ecological awareness and the good Anthropocene.
\end{abstract}

Global warming might just as well continue what Freud called the great humiliation of the human. Being added to a list of humiliators, which includes, according to Timothy Morton, Copernicus, Darwin, Derrida, Marx, and Heidegger, just to name a few, global warming brings human displacement to a new level since it forces us to acknowledge that "we are always inside an object" (Morton 2013, 17). Global warming, as a hyperobject, as something that is massively "distributed in time and space relative to humans" (Morton 2013, 1), makes humans grapple with the painful realization that there is no away. Global warming is nonlocal; it is everywhere: in the bodies, oceans, forests, and buildings, yet nowhere to be found. It is viscous, as it clings itself to everything. In the time of hyperobjects we discover "ourselves on the inside of some big objects (bigger than us, that is): Earth, global warming, evolution" (Morton, 2013, 118). Our human scale is proven insufficient to rule it all. The split between nature and culture, subject and object, human and planetary history was just a fallacy. Human and nonhuman temporalities are more enmeshed than previously thought: "Now we must concede what seemed impossible to contemplate humans as agents changing the course of the deep history of the Earth, or rather of the Earth's deep future, an event giving rise to what might be called "post-history." (Hamilton 2017, 13) Accepting human's geological agency, Timothy Clark would go on, "is to revise strongly notions of what is or is not historically significant" (Clark 2015, 52). Not only human history is historically significant, after all.

Margaret Atwood's world in Oryx and Crake is a human-altered environment in which a newly created race, the Crakers, and the narrator, Jimmy, a remnant of human race, survive the harsh conditions of an altered planet. Through Jimmy's faltering memory the story of the creation of this new race is told, along with the collapse of human race, its decimation by a lethal virus. Even though climate change as a reality exists since the beginning of the novel, all the scientific discoveries in the walled communities, the socalled compounds, seem to address this new reality: the Earth is getting warmer, nothing is changed in human behavior. Climate change does not play a role in Jimmy's life. If on the one hand, animals are becoming extinct; on the other hand, more animals are being bioengineered. If plants outside the compounds cannot survive the harsh reality of a warmer planet, inside, new plants, bioengineered ones, thrive and keep the temperature under control. Climate is under control within the walls of the compounds and life goes on as though nothing had happened. The compounds, therefore, as an attempt to go away, to escape the viscosity and nonlocality of global warming, may help shed some light on our modern constitution. This novel, obsessed with binaries as it is, the split between humanities and 
sciences, is a speculative exercise on how modernity conceives knowledge and its consequences. But mostly on how the split-nature and culture, humanities and sciences, object and subject-may prevent us from addressing the reality of climate change. Accepting its reality means going beyond the split, beyond the sovereignty of the subject; it means, in a nutshell, rethinking our cherished modern concepts, such as time, progress, and subjectivity.

Snowman/Jimmy lets us know right from the beginning of Margaret Atwood's Oryx and Crake that it is zero hour. As he looks at his watch, out of habit, he is overtaken by a feeling of desperation: "A blank face is what it shows him: zero hour. It causes a jolt of terror to run through him, this absence of official time. Nobody nowhere knows what time it is" (Atwood 2003, 3). Zero hour, as though time had been suspended, as though all progression had come to a halt and Snowman, formerly Jimmy, was stuck in this limbo, stuck between a past he cannot regain, a past that keeps slipping through his fingers, and a present with no future: "He doesn't know which is worse, a past he can't regain or a present that will destroy him if he looks at it too clearly. Then there's the future. Sheer vertigo" (Atwood 2003, 147). When did it happen, anyway? Snowman keeps asking himself. "He must have been five, maybe six" (Atwood 2003, 15). Remember the bonfire, Snowman? Remember that once upon a time you were called Jimmy? That once you had a mother and a father and then a stepmother and a friend and lovers, so many lovers? Remember when it was? "Several years passed. They must have passed, thinks Snowman" (Atwood 2003, 59). At this zero hour, this empty space Snowman seems to inhabit, his experience of time is reduced to "must haves." He must have been six, several years must have passed, but who can be sure of when it all happened? "There are a lot of blank spaces in his stub of a brain, where memory used to be" (Atwood 2003, 4).
Snowman's present is constantly interrupted by his past's replays, by flashbacks he cannot turn off, by voices that come out of nowhere, by sentences on fridge magnets, by words out of context, and even though the reader is presented with at least two different storylines, Snowman's present and past; all sense of progression is denied. The novel comes full circle when it ends with the same idea with which it had begun: "Zero hour, Snowman thinks. Time to go" (Atwood 2003, 372). Zero hour, once again. Is it the beginning or the end? A beginning and an end? One and the same?

Snowman's broken watch identifies the negation of time as a consequence of catastrophe in two different senses: first, the ending of the mechanical and social commodification of experience through the imposition of clock time and, second, an ending to history through the violent disruption of human memory and civilization. (Dodds 2015, 121)

There is no arguing against the sense of ending throughout the novel, against a post-apocalyptic last man experience that Snowman personifies. Until the very last minute, Snowman believes himself to be the only one alive: "Everything is so empty. Water, sand, sky, trees, fragments of past time. Nobody to hear him" (Atwood 2003, 11). Until the very last minute the narrative unfolds as a "world without us" experience, as Snowman, the last man alive after a virus destroys mankind, tries to survive by becoming a scavenger as he looks for and holds on to the last remnants of human experience. At the last minute, however, Snowman learns he is not alone; there are others, human beings, just like him, human beings still driven by the imagination Crake tried to destroy. The "world without us" narrative is about to become "us without a world" when it comes to an end: Time to go, Snowman announces. Time to go where? The lack of closure it presents seems to add just another layer to the ambiguities present in the novel as a whole. "End or beginning?" I ask.

Atwood's recovery of the zerohour expression at the end, her insistence on the stillness of the chronological time, in spite of the different stories presented in the novel, points to a puzzle to be solved: What is the relevance of time, or the framing of time, for the different levels of experience in Oryx and Crake? Since time is one of the guiding principles of our modern experience, our new experience as moderns, the novel as a whole, as "speculative fiction," keeps Modernity under scrutiny.

Hegel was, according to Habermas, the philosopher who inaugurated the discourse of Modernity. Hegel perceives Modernity's need for selfcertification since the models of the past would not be enough to grasp what modernity entails. Modernity's criteria should, therefore, be extracted from itself. It should be certified by its own norms, owing nothing to the pre-modern view of the world. Modernity's self-certification would be taken by Hegel as the guidepost of his philosophical concerns. Its guiding principle, subjectivity, guarantees Modernity's superiority (when compared to the pre-modern world) and is illuminated by the ideas of "freedom" and "reflection" (Habermas 2002, 25). The subjective freedom of the individual permeates modern culture and gains full expression, according to Hegel, in romantic art due to its absolute interiority. Subjectivity, however, is not restricted to the arts and, as a principle, organizes religious life, the State, and society as a whole.

Certain historical events were, nonetheless, crucial to the establishment of subjectivity, namely: the Reformation, the Enlightenment and the French Revolution. The Reformation led to the reflectiveness of the faith, inasmuch as tradition lost its authority to the sovereignty of the individual. The Declaration of the Rights of Man and Citizen and the 
Napoleonic Code, by focusing on the freedom of the will as the substantial foundation of the State, similarly, made the historical right lose its importance-as rights and ethics were no longer imposed from the outside, as God's commandments, but founded on man's will.

The expression "subjectivity" could have four different connotations, Habermas goes on: individualism-infinitely particular singularity; the right to criticism-that which is acknowledged by everyone should prove itself legitimate; autonomy of action - the possibility of answering for what we do; idealist philosophyphilosophy should ascertain that it knows what it is (Habermas 2002, 121). Modernity, therefore, by breaking away from the pre-modern world's parameters, by being established by means of "freedom" and "reflection," entailed a rupture in time. The term Modernity is not free from controversy, however.

For Marshall Berman, the history of Modernity has three different stages. The first one, when people start to experience modern life without being aware of what has hit them, begins in the sixteenth century and continues to the end of the eighteenth century. The second stage began in 1790, when a sense of living in a revolutionary time provoked profound changes. In its third stage, the twentieth century, Modernity loses its capacity to make sense of things, an era that has lost touch with its roots. (Berman 2007, 25-26).

Kumar, however, does not understand the seventeenth century as the beginning of Modernity. Except for Descartes, who, in Discourse on the Method, rejects older modes of thinking in order to establish a new way of thinking based on human reason, developing, this way, a new method to search for truth; as a whole, the accomplishments of the moderns were related to the idea of decadence (Kumar 1997, 89). For progress and growth, mankind had to pay a price, that is, moral and spiritual decadence.
Throughout the seventeenth century persists the return of an apocalyptic thought that limits the interest in the present. The present becomes a moment of preparation and waiting for a future that will be the result of a divine intervention. Human action plays no role in it. Only in the second half of the eighteenth century would this perception of time and history gradually give way to a new concept of Modernity (Kumar 1997, 91). In order for the idea of Modernity to be fully developed, there was the need to exorcize the apocalyptic view of the world, a condition that was fulfilled through only the secularization of Christian time in the eighteenth century. Modernity was no longer a degenerate copy of the ancient times; quite the contrary, it begins to mean an opening of pathways, a rupture with the past, an opening up to a time of unprecedented progress (Kumar 1997, 91). The moderns are, thus, those who live in a whole new world and should rely on themselves to discover new ways of acting and thinking. The "new" is a value, or "time's irreversible arrow," in Latour's terms (1993, 10).

The human condition, Crake would counter argue, is the "wish to stop time" (Atwood 2003, 292). In the face of death, human beings, as opposed to other species, will procreate as a last attempt to cheat death, to live on, to reach for immortality-to stop time as though reversing the arrow that points to the grand finale of us all: death. Crake's sentence seems at first a simple response to Jimmy's question: "What pays for all this?" (Atwood 2003, 292), but what follows this ironic, detached, cynical response, is Crake's disclosure of the BlyssPluss pill, whose justification is "we're running out of spacetime" (Atwood 2003, 295). There is little time, not enough time, before the whole species is doomed, hence "grief in the face of inevitable death" (Atwood 2003, 292). The BlyssPluss pill would provide mankind, at least the remnants, with a chance for a better future. Its benefits, protection against sexually transmitted diseases, unlimited supply of libido, and a prolonged youth, would be its selling points; what would not be advertised, however, were its birth control effects. Crake's interest does not reside in its benefits, though. The benefits would only attract the buyers, guarantee that it would reach a larger number of the population by appealing to the so-called human nature: "The tide of human desire, the desire for more and for better, would overwhelm them. It would take control and drive events, as it had in every large change throughout history" (Atwood 2003, 292). "More and better," Crake says, is the guiding force behind the impulse for newness, for an improved experience of sex. The pill would, this way, revolutionize human interaction by appealing to their need for newness, for what seems to drive human beings. The search for "more and better," the same one that had led to the scarcity of space-time, would, this time, buy mankind more time, reverse time's irreversible arrow, provide a better chance for human beings. In the face of the impending death, mankind's extinction, Crake attempts to stop time.

Lara Dodds, in Death and the 'Paradice within' in Paradise Lost and Margaret Atwood's Oryx and Crake, places Oryx and Crake within a science fiction tradition that responds to Milton's Paradise Lost. In Atwood's novel, Crake's plan aims at reversing the myth of the Fall, according to Dodds. The new race of men would inhabit a new Eden, where the consciousness of death would be inexistent. After eating the fruit from the tree of knowledge of good and evil, Adam and Eve become aware of their mortality. All of a sudden, they realize they are ashamed of their nude bodies. They are made aware of the corporeal components that make them who they are: bodies that rot, bodies that die. Conversely, the bioengineered race that Crake envisions has no consciousness of 
death. The physical aspect of death still exists, though, since their bodies are programmed to die. "The children of Crake," however, do not know they will eventually die and are kept in this state of innocence, in a bioengineered Eden in a postapocalyptic world. Crake wishes to stop time, then, by reversing mankind's state to that before the consciousness of death, before mankind was determined by the flux of time: "To be subject to death, as Adam and Eve are following the Fall, is to be subject to the gap between the duration of one's life and the shape of time. It is in this sense that human history can be said to begin with the Fall [. . .]" (Dodds 2015, 128). Stopping time, in Crake's terms, could have at least two meanings. Firstly, it could mean the illusion of immortality. Not knowing about the existence of death means not suffering in anticipation, which would result in not acknowledging the passing of time. Secondly, it could prolong the existence of this newly created race. Fewer individuals who were more adaptable to the climate change and the hazards posed by an altered environment would probably pose fewer threats to the environment, guaranteeing both the permanence of the species and the world. Stopping the time, however, would be possible only by modifying the "human nature" through the stages of his plan. First the pills, as Crake points out, "The BlyssPluss Pill was designed to take a set of givens, namely the nature of human nature, and steer these givens in a more beneficial direction than the ones hitherto taken" (Atwood 2003, 293). The pill that would end up killing basically all human race, except for a couple of individuals, would do so by "manipulating" the so-called nature, by making nature work in favor of a previously designed plan. After massive extinction, a newly improved race would take over. The Paradice Project is its name. By altering the ancient primate brain, destructive features such as racism, hierarchy, territoriality, and torments due to sexuality would be eliminated, and these perfected beings would repopulate the world in their eco-friendly way. There is a catch, though, as Crake warns Jimmy:

Watch out for art, Crake used to say. As soon as they start doing art, we're in trouble. Symbolic thinking of any kind would signal downfall, in Crake's view. Next they'd be inventing idols, and funerals, and grave goods, and the afterlife, and sin, and Linear B, and kings, and then slavery and war. (Atwood 2003, 361)

Crake's concerns seem to resonate with that of Raphael's in Milton's Paradise Lost. "But apte the Mind or Fancie is to roave / Uncheckt, and of her roaving is no end" (Milton 1952, 236), Raphael warns Adam. Beware of the imagination; soon enough you will be thinking of worlds invisible; you will be imagining things remote from your daily life; soon enough you will be transgressing, I ask, is that so? Curiously, Lucifer, right after being expelled from Heaven for not abiding by a decree that, logically, offended the principles by which all the angels had lived until then-equality and freedom-, realizes that no matter where he is, Heaven or Hell, one thing remains inalterable: "A mind not to be chang'd by Place or Time" (Milton 1952, 99). His resistance, therefore, against a tyrannical decree is his own mind. Much better to be free in Hell than to serve in Heaven since: "[ $t$ ]he mind is its own place, and in itself / Can make a Heaven of Hell, a Hell of Heaven" (Milton 1952, 99). "A Heaven of Hell, a Hell of Heaven," says Lucifer, highlighting, this way, the mind's reflective power. The reflection is made visible by means of an inversion of the word order. The physical (visible) presentation of the verse matches its content meaning; there is no disjunction between signified and signifier, as both point to the idea of reflection. Reflection, mirror, speculation-what does the mind do? The mind speculates and, by doing so, changes the reality of all the things around. Heaven can be hell and hell can be heaven, as long as the mind wishes it to be so. The possibilities are endless, warns Raphael. Without limits, boundaries, limitations, the roaving has no end. Men can imagine, Crake would go on, that there is a life after death, that there is a soul, that the soul leaves the body when we die, that our soul lives on in another dimension, that poetry could reach immortality, that there is a God and there is a Nature: "I don't believe in Nature either," said Crake. "Or not with a capital N" (Atwood 2003, 260). What does it mean to believe in nature with $\mathrm{n}$ as opposed to nature with $\mathrm{N}$ ? What changes when you think of Nature as a subject or as an object?

It means that for Crake the concept of Nature had been surpassed, that we would be living in a post-nature world. Christophe Bonneuil, in The Geological Turn: Narratives of the Anthropocene, understands that the term post-nature may have different meanings. Modernity's discourse has always been that of human race freeing itself from natural determinism. Reflection (consciousness) enabled mankind to gain more and more freedom with the passing of time. Progress was hence the combination of reflection and freedom. More consciousness meant more freedom and subjective freedom; according to Hegel, it permeated the modern times. The separation between culture and nature is, nonetheless, questioned whenever the concept of the Anthropocene is brought into discussion. Conceiving the entire species as a geological force that altered the Earth means that both realms-human and planetary-are more enmeshed that previously thought. What is more, the different 
temporalities-planetary and human-are not separated, after all. Climate change, the acidification of the oceans, earthquakes and tsunamis, the scarcity of "space-time," as Crake mentions, play a role in human history. There is no human history without its natural counterpart. Nature is not a backdrop to human history, then, since nature and culture were never really separated. The so-called Great Divide was nothing but a fallacy, in Latour's terms, as we have never been modern. Nature with a capital $\mathrm{N}$ is just a romantic construct, Crake would say. The acceptance of this post -nature idea would, on the one hand, instill humility in our dealings with the planet, since the human exceptionalism paradigm would be discredited; on the other hand, it would lead to what is called "the good Anthropocene":

[T] here will no longer be an environment that is external (read: hostile) to humankind. Not so much because man will be transfigured by technology, as Singularitarians dream, but because the old Nature will be recodified (or rather re-axiomatized) by the capitalist machine as merely a matter of managing resources, of environmental governanceeverything according to so-called "best practice." The anthropic dream of the Moderns would thus be finally materialized: a post-environmentalism in which man will find himself contextualized and sustained only by himself, surrounded by the immense accumulation of commodities, energized by his shiny new and super-safe nuclear centrals (with cold-fusion reactors, if possible), and relaxed by large and pleasant ecological leisure areas, populated of course by a carefully curated, genetically enhanced flora. (Danowski and Viveiros de Castro 2017, 49)

Oryx and Crake's two main storylines, Snowman's present and past, take place in different moments of the good Anthropocene. Jimmy's life, in the compounds, in Martha Graham, is surrounded by technology, bioengineered foods and even pets; a life behind the walls of the compounds where everything is orderly and controlled, where surveillance is the norm and people cannot come and go as they wish. Living in the compounds is similar to living in a bubble, artificially protected from the harsh environmental change all around. No wonder do climate change and catastrophes take the form of as a matter of fact comments, almost as footnotes, rushed descriptions that seem dislocated from the main action:

Still, as time went on and the coastal aquifers turned salty and the northern permafrost melted and the vast tundra bubbled with methane, and the drought in the midcontinental plains regions went on and on, and the Asian steppes turned to sand dunes, and meat became harder to come by, some people had their doubts. (Atwood 2003, 24)

According to Adam Trexler, climate change

is little more than a footnote to the novel's concerns. Atwood describes a world where hierarchical, corporate capitalism and biotechnologies allow the unprecedented exploitation of human bodies. The world population is decimated by a virus engineered in the center of the corporate machine, and a new race of posthumans is positioned to live more sustainably. (Trexler 2015, 196)

Climate change is not a concern in the novel. It is, though, the context in which new technologies emerge. It is the context that propels more and more scientific advances. The search for "more and better" that endowed mankind with geological agency continues to be the impulse behind the walls of the compounds. Science responds to environmental change and the new demands imposed by an al- tered environment. Climate change is, then, a concern in the novel. How does one live in an altered world, the novel asks itself. For which humans do climate change and environmental disasters beg? How can anyone guarantee the permanence of the human in this post-nature epoch? The novel is, therefore, about human agency in the face of environmental collapse: human stewardship, living in the good Anthropocene. When the first attempt seems to fail, when there is still scarcity of "space-time" in spite of it all, Crake puts his plan into action: a new race, a perfected race, a bioengineered race. Crake wishes to stop time, to restart the world, to go back to the basics.

Climate change is beyond the gates of the compounds. In these walled spaces, where science and money are combined, any sea level alteration, scarcity of meat, animal extinction and increase in the global temperature are being mitigated by new biotechnologies and technologies that allow for comfortable living spaces. Climate change is, as a reality, almost surpassed, a thing in the past, being brought up when the past is evoked: "[. . .] like the beach house her family had owned when she was little, the one that got washed away with the rest of the beaches and quite a few of the eastern coastal cities when the sea-level rose so quickly, and then there was that huge tidal wave, from the Canary Islands volcano" (Atwood 2003, 63). The compounds are, thus, a post-nature, postclimate change world. The compounds are as well, not only a reality, spaces of status and power, but also the great metaphor for a novel obsessed with boundaries, walls, limits, and binaries.

The Compounds encapsulate corporate "yes" culture in a spatial metaphor of bringing together into one place all those who have "opted in," who have internalized the goals, truth, and ethics of the company as their own, and excluding or expelling everything that is threatening to this homeostasis. (Crooke 2006, 


\section{9)}

Since the beginning of the novel we are told that there are two categories of people: numbers or word people. Crake fits the numbers person profile, whereas Jimmy falls under the word person category. The duality permeates the novel, being recurrently brought up, and helps understand both characters' successes and failures. Their scientific or rhetoric-linguistic abilities are key factors determining not only the colleges they attend and the job offers they receive but also where they live. In a techno-scientific society, where nature has been surpassed and climate change is in a once -upon-a-time framework, being science-oriented, or a numbers person, in Atwood's words, is really profitable. Since the compounds are sciencedriven spaces, the best scientists have the best paying jobs and live in the best compounds. The search for "more and better" leads to different house moves and determines how contingent relationships are: "Kids came and went, desks filled and emptied, friendship was always contingent" (Atwood 2003, 71). Underlying all this scientific talk, however, is the true catalyst of societal changes: money.

Scientific and research interests do not exist in themselves, though. The novel does not present a science for science's sake tale; quite the contrary, scientific interests are circumstantial, more based on demands than investigative nature. Science is just a commodity, a pretty lucrative one, I must add.

The split between numbers people and word people, or in broad terms, between science and the humanities, can be understood as Stephen Dunning does, as a means to extrapolate the fields division and warn against its consequences. Oryx and Crake would, thus, be a cautionary tale about the dangers of conceiving scientific knowledge without taking human concerns into consideration. The human concerns should mediate scientific knowledge, should put the brakes on the ambition for "more and better" as the ambition for more money.

Crake's character embodies the clear split between the different fields of knowledge: "His clothes were dark in tone, devoid of logos and visuals and written commentary-a no-name look." (Atwood 2003, 72) Even through his choice of clothes, Crake displays his lack of affinity with words. Crake's "laconic" look may be read as a metaphor for his behavior toward the world. Clothes are supposed to be clothes and nothing more and should serve the purpose of covering his body. Everything exist for a reason, according to Crake: "Crake is a biological determinist, believing also in a logical biology, a biologic of sense. Art, for instance, exists for a purely biological function" (Crooke 2006, 77). Art, as well as words, serves a purpose and that is all.

Even though Jimmy is the classic example of a word person, both friends are much more alike than expected. Being a word person or a numbers person does not mean being complete opposites, it means, nonetheless, occupying different walled spaces: "There had been something willed about it though, his ignorance. Or not willed, exactly: structured. He'd grown up in walled spaces, and then he had become one. He had shut things out." (Atwood 2003, 184) Jimmy shuts things out, as well as Crake does, as well as the compounds do. There are different levels, therefore, of shutting things out, in the novel. As mentioned before, through the characters, the spaces, lines, stories, the novel unfolds its obsession with boundaries, limits, limitations. "Watch out for art," Crake says, establishing another boundary for his post-humans, "the children of Crake”. But why art, Crake, I ask?

Throughout the novel, Snowman struggles with language. There is a sense that language is slipping away from him, that little by little, he is forgetting words, meanings. "Hang on to the words," he tells himself. "The odd words, the old words, the rare ones. Valence. Norn. Serendipity. Pibroch. Lubricious. When they're gone out of his head, these words, they'll be gone, everywhere, forever. As though they had never been" (Atwood 2003, 68). Why the old words, Snowman?

Since Snowman believes he is to be the last of his kind alive, some words may only exist in his mind. They are the remnants of a past type of living, of a past type of human-rare words, old words, like himself, a rare human being so different from the perfected beauty of "the children of Crake." When he is gone, human life as it is, as well as human language, may disappear forever. Crake's perfected human beings still use language to communicate but do not know malice, "but these people didn't go in for fancy language: they hadn't been taught evasion, euphemism, lily-gilding. In speech they were plain and blunt" (Atwood 2003, 348). Their use of language was much more practical, daily, and literal. Why would they need to resort to a concept such as serendipity, so far removed from their daily concerns, so distant from their new reality? Snowman's language refers to a long gone type of experience: "I used to be erudite," he says out loud. Erudite. A hopeless word. What are all those things he once thought he knew, and where have they gone? (Atwood 2003, 148). Outside the compounds, however, beyond the walled world, the walled experiences, the closed-in world of well-established knowledge, beyond the sovereignty of the subject, what was previously known does not suffice to account for this new world. Words fade, lose their solidity, and become, all of a sudden, insufficient; all of a sudden, wisdom is turned to folly, as Raphael imagined it would. Once the boundary is transgressed, knowledge, words, concepts become slippery, contingent, empty.

Another dimension to Snowman's concerns exists, however. After the world surrounding him changes, he tries to hold on to what is still familiar, as though trying to compensate for the loss of control. He had always been a word person, someone who found his way around the science-driven world by using his linguistic skill. Publicity was his way around. Publicity, nonetheless, entails a specific relationship to the words: "Reading a poem introduces some wiggle room between ideas and ways of having them. Propaganda closes this space down" (Morton 2018, 30). The words would hence be at Jimmy's disposal. Jimmy's attitude, 
reaching out and grabbing the words, making them mean what he wanted them to, mastering the words, resembles Crake's attitude toward the world. Numbers people or word people seem much more alike than expected. As Timothy Morton warns us, "It's not what you think but how you think that starts World War III" (Morton 2018, 33). It's not what you think-scientific or human concerns-but how you think. In Oryx and Crake, science serves a purpose as well as the words do. It is thus the apotheosis of the subject-object dualism, the demise of a world where anything that could was objectifiedcommodification, plain and simple. When the walls between the perfect, engineered human world and the world around cracks, when humans lose control over a world that can no longer be programmed, predicted, words falter. Is the experience unimaginable? Does it surpass our too human abilities to conceive the world? Was wisdom turned to folly?

Just the human wish to stop time, as Crake warns us, but whose time, I ask? Crake's Paradice Project and his attempt to deny the posthumans, the newly created race, the consciousness of death is an almost too literal way to reverse the fall of men. The newly created race would be kept in this eternal innocence, leading a more eco-friendly mode of living. It is also an attempt to start again with a clean slate.

"Everything emits time, not just humans" (Morton 2018, 77). So whose time should be stopped, I ask? All experience of time, Crake would say. In no circumstances do non-humans enter into Crake's equation. Their temporalities are never acknowledged. Even when environmental disasters hit the globe, modifying life as it was, the non-human world continues to be shut out. Mankind finds a way to banish the non-humans, to deny their temporalities, to stop the time. The compounds, therefore, are a means to avoid any ecological awareness: "Ecological awareness is shaking our faith in the anthropocentric idea that there is one scale to rule them all-the human one" (Morton 2018, 22). The human scale continues to rule it all until the scarcity of "spacetime" is such that denial is not a possibility anymore. Space and time, two a priori conditions of human sensibility prove themselves to be conditioned after all. "This is one of the ways, and not the least important, in which it can be said that our world has ceased to be Kantian" (Danowski and Viveiros De Castro 2017, 9). Men were proven unable to rise above the phenomenal order or causality. They were not the lawgivers of nature, after all, but phenomenologically bound to and conditioned by the human and non-human world: "You aren't outside the biosphere looking in. You are glued to the biosphere phenomenologically" (Morton 2018, 41). The boundaries were, this way, not enough. They are more porous than anticipated. Crake, nevertheless, instead of accepting the porosity of the boundaries, instead of acknowledging the non-human world, decides to put an end to human life as it was, to go back to the beginning, but with a twist. This clean slate is, however, still conditioned: "Watch out for art," Crake used to say. "As soon as they start doing art, we're in trouble. Symbolic thinking of any kind would signal downfall, in Crake's view" (Atwood 2003, 361).

Art determined whether the project was successful or a failure. Imagination's rove has no end, Raphael warned Adam it knows no boundaries, we can infer. Imagination brings visibility to the invisible realm; it establishes connections that are not apparent. Raphael equates fancy with the mind, as though both were one and the same, as though they shared similar characteristics. Fancy's rove had no end, as well as the mind's. Lucifer would agree: the mind is its own place; it had the power to alter space and time; it had the power to be a place of resistance. For Lucifer, the mind became a symbol of freedom. How does he free himself from the divine decree and all its constraints? Through his mind. Lucifer became a subject then:
He is a "subject" in our contemporary theoretical sense (the "humanist subject"), and certainly his troubled "I" is prominent in the poem. But he is a "subject" also in the more literal, root sense of the term (sub iectus, thrown under): he discovers at the moment of his rebellion just what it means to be subject to God. Subjection is the origin of his subjectivity. (Forsyth 2003, 150)

His search for freedom, for the unconditioned, is the origin of his subjectivity. So, the new race, "the children of Crake," could stand a chance only if subjectivity would not emerge-if the principle behind the idea of Modernity, as Hegel states, did not guide the progress of mankind? The problem is not what you think, Timothy Morton would argue, but how you think.

Snowman learns that the Crakers, in spite of Crake's efforts to eliminate any symbolic thinking, the Gspot in the brain as he calls, are curious about their origins, are eager to create narratives: "They're up to something though, something Crake didn't anticipate: they're conversing with the invisible, they're developing reverence" (Atwood 2003, 157); singing and dreaming were not the only things humans were hard-wired for. Symbolic thinking seems to be part of human nature. Human's demise again? Zero-hour, Snowman lets us know.

What if subjectivity allowed for a new experience, one in which walled spaces were not a reality and shutting things out were not the norm? What if we did not let anything go, anything pass, as Isabelle Stengers suggests we do (Stengers 2015, 143)? What if we took full responsibility for the reality of our abstractions? What if we loved our monsters?

"Watch out for art," Crake says. There is no denying that symbolic, abstract thinking allows for appropriation, for eliminating any other scale rather than the human one; yet isn't 
there another side to it? The aesthetic experience entails solidarity to what is non-human, Timothy Morton would reply, caring for something that is not another human being. What is more, beauty is indifferent to the subject. The aesthetic experience might just as well, due to its weirdness (Morton 2018, 65), provide us with the hint of the uncanny necessary to overthrow the sovereignty of the subject: "this feeling of openness, this uncanny sensation of finding ourselves somewhere and not recognizing it, is exactly a glimpse of living less definitively, in a world comprised almost entirely not of ourselves" (Morton 2018, 26). Living less definitively might be the key, then?

"It's Zero-hour," Snowman says. It's time to go.

\section{References}

Atwood, Margaret. 2003. Oryx and Crake. New York: Anchor Books.

Berman, Marshall. 2007. Tudo que é sólido desmancha no ar. São Paulo: Companhia das letras.

Bonneuil, Christophe. 2015. "The Geological Turn: Narratives of the Anthropocene." In The Anthropocene and the Environmental Global Crisis: Rethinking Modernity in a New Epoch. London:

Routledge: 15-31.

Chakrabarty, Dipesh. 2012. "Postcolonial Studies and the Challenge of Climate Change." New Literary History, 41 (1): 1-18. doi: 10.1353/nlh.2012.0007.
_-_. 2009. "The Climate of History: Four Theses." Critical Inquiry, 35 (2): 197-222. doi: 10.1086/596640.

Clark. Timothy. 2015. Ecocriticism on Edge: The Anthropocene as a Threshold Concept. New York: Bloomsbury Academic.

Crooke, Grayson. 2006. "Technics and the Human at Zero-hour: Margaret Atwood's Oryx and Crake." Studies in Canadian Literature, 31 (2): 63-83.

Danowski, Déborah, and Viveiros de Castro, Eduardo. 2017. Há mundos por vir? Ensaio sobre os medos e os fins. $2^{\text {nd }}$ ed. Florianópolis: Instituto Socioambiental. -. 2017. The Ends of the World. Cambridge: Polity Press.

Dodds, Lara. 2015. "Death and the 'Paradice within' in Paradise Lost and Margaret Atwood's Oryx and Crake." Milton Studies 56: 115-150.

Forsyth, Neil. 2003. The Satanic Epic. Princeton: Princeton University Press.

Habermas, Jürgen. 2002. O Discurso Filosófico da Modernidade. São Paulo: Martins Fontes.

Hamilton, Clive. 2017. Defiant Earth: the Fate of Humans in the Anthropocene. Sydney: Allen and Unwin.

Kumar, Krishan. 1997. Da Sociedade Pós-industrial à Pós-moderna: Novas Teorias Sobre o Mundo Contemporâneo. Rio de Janeiro: Jorge Zahar (ed.).
Latour, Bruno. 1993. We Have Never Been Modern. Cambridge: Harvard University Press.

Milton, John. 1952. Paradise Lost. Chicago: Encyclopaedia Britannica.

Morton, Timothy. 2018. Being Ecological. Cambridge: The MIT Press.

———. 2013. Hyperobjects: Philosophy and Ecology after the End of the World. Minneapolis: University of Minnesota Press.

Scranton, Roy. 2015. Learning to Die in the Anthropocene. San Francisco: City Lights Books.

Stengers, Isabelle. 2015. "Accepting the Reality of Gaia: A Fundamental Shift?" In: The Anthropocene and the Environmental Global Crisis: Rethinking Modernity in a New Epoch. London: Routledge,: 134-144.

Trexler, Adam. 2015. Anthropocene Fictions: The Novel in a Time of Climate Change. Charlottesville: University of Virginia Press. 